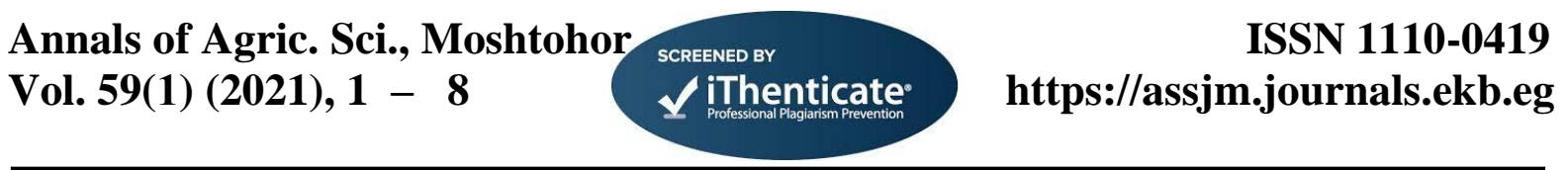

\title{
Effect of Planting Dates and Weed Control Treatments on Soybean Yield and Its Components
}

\author{
Asmaa M. Hamoda; G. A. Sary; ELsayed Shokr and A. Roshdy \\ Department of Agron. Fac. of Agric., Moshtohor, Benha Univ. Egypt \\ Corresponding author: asmaa.hamoda@fagr.bu.edu.eg
}

\begin{abstract}
Two field experiments were conducted at Agricultural Research Farm of the Faculty of Agriculture, Benha University, Egypt, during two growing seasons of 2018 and 2019 to investigate the productivity of soybean (Glycine max L.) under different sowing dates (May 5, May 20 and June 3) and weed control treatments (no weeding (control), two hand weeding at 20 and 40 DAP, and chemical control by the pendimethalin (omega herbicide) at rate of $1.7 \mathrm{~L} /$ fed and the oxyflurofen (goal) at a rate of $0.750 \mathrm{~L} / \mathrm{fed}$ as pre-planting herbicide]. Results of the combined analyses of the two seasons showed that sowing in May 5 significantly increased weight of pods, No. and seed weight/plant $(\mathrm{g})$ and seed yield $(\mathrm{kg} / \mathrm{fed})$ compared with other treatments. Each of the weed control treatments as spraying omega herbicide and application of hand hoeing twice increased weight of pods, No. of seeds/plant and seed yield/fed compared to their control and the goal herbicide application. The maximal straw and biological yield of 2907.51 and $4101.92 \mathrm{~kg} / \mathrm{fed}$, respectively were recorded following the application of the goal herbicide. Also, the interaction between earlier planting date (May 5) and hand hoeing twice recorded the maximum values for the number of pods (67.65 pod/plant), weight of seeds (19.63 g/plant), 100 -seed weight $(19.12 \mathrm{~g})$ and seed yield $(1427.67 \mathrm{~kg} / \mathrm{fed})$.Also, results show that soybean plants sowing in May 5 with hand hoeing twice or using weed herbicides led to increased seed yield/fed. And its components under experiment soil conditions.
\end{abstract}

Keywords: Soybean; planting date; Seed yield; Weed control; Herbicide.

\section{Introduction}

Soybean (Glycine max L.) belongs to the family Fabaceae. It is one of the main oilseed crops in the world. Among the legume crops, soybean contains the highest amount of protein $(40 \%)$, good amount of oil $(20 \%)$ and it has a good quantity of other nutrients such as calcium, phosphorus, iron and vitamins (Rahman, 2001; and Devi et al., 2012). Soybean is an important food legume that is used for different purposes including human food and animal feed. It is grown in many parts of the world and is of primary source of vegetable oil and protein for food and feed applications. It also has a balanced amino acid profile and its protein has great potential as a major source of dietary protein and can play an important role in solving malnutrition problems (Ruhul et al., 2009).

In Egypt, although the production area of soybean increased from 2841 fed on 1972 to 36.000 fed on 2018, and the yield varied from 477 on 1972 to $1033 \mathrm{~kg} / \mathrm{fed}$ on 2018 (FAO, 2018). However, suffering from a severe shortage of more than $95 \%$ of our needs from its edible oils. Therefore, to stabilize and improve the productivity of soybean, a new strategy/policy is required for both genetics and agronomic management as planting dates and weed control treatments.

The optimization of planting date is an imperative and least expensive agricultural strategy that influence soybean yield (Robinson et al. 2009). Moreover, Chen and Wiatrak (2010) reported that late sowing dates can reduce period of the vegetative period, flowering, pods set, and to a less extent, seedfilling period. Ray et al. (2008) observed that the early planting date (late May) resulted in improved plant height, seed yield, protein and oil contents as compared with late planting date (late June). They also found that late planting date led to later maturity dates, larger seed size, and higher seed quality than of early planting date. Zhang $\boldsymbol{e t}$ al. (2010) observed that soybean yield reduced by 34 to $55 \mathrm{~kg} \cdot \mathrm{ha}^{-1} \cdot \mathrm{d}^{-1}$ with a delayed planting time and this decreased of yield was ascribed to the reduction in No. of pods/plant and enhanced fresh weight of seed which might stimulate the loss of yield at full seeding stage. A reduction in yield due to late sowing is probably due to the shortened duration from planting to flowering and to maturity (Bastidas et al. 2008). Also, El Toum et al. (2020) indicated that sowing time significantly influenced $(\mathrm{p}<0.05)$ the yield parameters of soybean including weight of 100 -seed, harvest index and seed yield. They also noticed that sowing time at July, 1 enhanced seed yield by $72 \%$ over the delayed planting date (July 15). Photoperiod and temperature are the two substantial factors affecting soybean development (Sinclair et al., 2005). Photoperiod changes the temperature response in soybean plant with longer day length and reducing the rate of development through delaying the reproductive phase which decreases and/or delays the flowering stages, which because of longer day length at the later sowing time and resulting in the decrease of seed yield (Setiyono et al., 2007).

Das et al. (2010) indicated that weeds can cause computational stress on soybean growth especially 
during first 30 days from sowing and reduction of the yield by $58-85 \%$, depending on the intensity of infestation. Pinke et al. (2016) stated that the abundance of some weed species was strongly influenced by the environmental and agronomic conditions and its infestation could be more efficiently managed by the proper selection of herbicides. Abd El-Hamid and El-Metwally (2008) observed that two hand hoeing treatments increased No. and weight of pods/plant and No. of seeds/plant by $140.7,150.0$ and $59.8 \%$, respectively as compared with the non-weeded treatment (control). Seed yield of soybean was maximized from 508 to $858 \mathrm{~kg} / \mathrm{fed}$ when used bentazon herbicide at a level of 0.75 L/fed. Also, they observed that fresh and dry weights of the narrow, broadleaved and total weeds were significantly reduced by weed management practices as compared to the non-weeded treatment.

In literature, there are several studies on the yield and yield components of soybean. Nevertheless, to the best of our knowledge, the supporting data and/or the fundamental information regarding the effect of planting date and weed control on soybean yield attributes are limited. Therefore, the objectives of this research were aimed to: (i) investigate the effect of sowing date and weed control on soybean yield and its components; and (ii) examine the combined impact of planting dates and weed control on the productivity performance of soybean.

\section{Materials and methods}

Two field experiments were conducted in two summer seasons (2018 and 2019) at the Agricultural Research Farm, Faculty of Agriculture, Benha University, Egypt, to investigate the productivity of soybean under various planting dates (May 5, May 20 and June 3); weed control treatments (no weeding (control), two hand weeding at 20 and 40 DAP, and chemical control by the pendimethalin (omega herbicide) at rate of $1.7 \mathrm{~L} /$ fed and the oxyflurofen (goal) at a rate of $0.750 \mathrm{~L} / \mathrm{fed}$ as pre-planting herbicide].

The experiment was laid out in a split plot design with four replications. Planting dates were allocated in the main plots and weed control treatments in sub-plots. The plot area was $10.5 \mathrm{~m}^{2}$ $(3 \times 3.5 \mathrm{~m})$ and each plot consists of 5 rows of spaced $60 \mathrm{~cm}$ apart and $3 \mathrm{~m}$ along.

The earlier winter crop was berseem clover (Trifolium alexandrinum L.) in the two growing seasons. The experimental field was prepared and then fertilize with super phosphate $\left(\mathrm{P}_{2} \mathrm{O}_{5}\right)(15.5 \%)$ fertilize at the rate of $150 \mathrm{~kg} / \mathrm{fed}$ was added. Herbicides were applied as pre planting procedure at a rate of $200 \mathrm{~L} / \mathrm{fed}$ on soil surface followed by irrigation. Soybean seeds were thoroughly inoculated with Bradyrhizobium japonicum strain before sowing. Seeds were hand sown in hills spaced $20 \mathrm{~cm}$ on single ridges. Seeds rate of $30 \mathrm{~kg} / \mathrm{fed}$ were sown at a soil depth of 3 to $5 \mathrm{~cm}$. After three weeks from planting, plants were thinned (two healthy plants) on each hill. Afterward, nitrogen fertilizer was added in the form of urea $(46.5 \% \mathrm{~N})$ at the rate of $15-20$ $\mathrm{kg}_{\mathrm{N}} / \mathrm{fed}$. The rest of the agricultural/agronomic practices for growing soybean were followed as the recommendations properly for soybean cultivation.

\subsection{Data collection}

At harvest, a sample of 5 plants was randomly selected from each plot of the four replications to determine the soybean yield and its components including plant height $(\mathrm{cm})$, No. of pods/plant, weight of pods (g/plant), No. of seeds/plant, weight of seeds (g/plant) and weight of 100-seed (g). Furthermore, plants were taken from the two middle ridges in each experimental unit from the four replications to estimate seed, straw and biological yield/fed $(\mathrm{kg})$

\subsection{Statistical analysis}

Data were statistically analyzed using MSTAT statistical package (MSTAT-C with MGRAPH version 21). The combined analysis was conducted for data of the two seasons after testing the homogeneity of error variances according to Gomez and Gomez (1984). Fisher's Least Significant Differences (LSDs) were determined at 0.05 significance level as described by Snedecor and Cochran (1980).

\section{Results and discussion}

\subsection{Planting dates \\ 3.1.1. Plant height}

Data in Table (1) clarified the impact of different plant dates (May 5, May 20 and June 3) on plant height of soybean. Results of the existing study proved that plant height clearly increased $(p<0.05)$ when planting at May 5 and 20 over late sowing date at June 3, whereas differences were not significant among the early (May 5) and the middle (May 20) planting date $(\mathrm{p}>0.05)$. Tallest plants $(99.53 \mathrm{~cm})$ were recorded when planting on May 20, but the shortest plants were noticed $(86.70 \mathrm{~cm})$ in June 3 . These observations were probably credited to the relatively longer duration of growth when the optimal environmental conditions including temperature and solar radiation, produced an increase in plant height at May 20.

\subsubsection{No. and weight of pods /plant}

Significant differences were observed for the No. and weight of pods/plant due to the early and middle planting as compared with late planting of June 3 (Table 1). However, No. and weight of pods/plant exhibit no difference among early and middle sowing date $(p>0.05)$. The maximal No. of pods (61.53 pod/plant) was obtained from planting 
on May 20, whilst the minimal (55.92 pod/plant) was noticed when the delayed planting time at June 3 . This outcome may be due to the higher No. of stem nodes, causing an enhancement in No. of pods/plant during the middle sowing (May 20).

Kumar et al. (2005) reported that early sowing (end May to early June) provides long vegetative/ reproductive growth durations. Thereby increasing biomass production of the crop, which enhanced the No. of pods per plant and seeds per pod. Besides, planting at May 5 produced the highest weight of pods/plant $(28.90 \mathrm{~g})$ whereas the lowest weight $(22.74 \mathrm{~g})$ was found at June 3 . These results are similar with to the observations of kumagai (2018).

\subsubsection{No. and weight of seeds/plant and weight of 100-seed}

The effects of various sowing dates on No. and weight of seeds/plant and 100-seed weight of soybean plant are recorded in Table (1). Such observations indicated that there were no significant differences between the two planting dates (early and middle-May) on these measured parameters, except for No. of seeds/plant. Planting in May 5 and 20 have remarkable effect $(\mathrm{p}<0.05)$ on No. and weight of seeds/plant and 100-seed weight in comparison with control group. Additionally, highest No. and weight of seeds (93.39 seed/plant and $17.17 \mathrm{~g} / \mathrm{plant}$, respectively) which were observed from early planting on May 5 however, the minimal values (69.48 seed/plant and $13.60 \mathrm{~g} / \mathrm{plant})$ were obtained from the delayed planting time at June 3 . The reduction in No. and weight of seeds/plant was possibly linked to the exposure of flowers to the high temperatures at the beginning of the season, resulting in incomplete growth, seed damage, and empty pods, which reduced the No. and weight of seeds/plant at late sowing date. Similar results were reported by Yari et al. (2013).

On the other hand, planting at May 20 significantly enhanced the 100 -seed weight (18.45 g) above sowing in May 5 (17.97 g) and June 3 (16.24 g). This result may be associated with the short vegetative growth duration period, long reproductive and seed filling duration that improved of 100-seed weight. Also, this enhancement in the 100-seed weight is probably correlated with the ability of soybean plants for improving the enhancement of photosynthesis, causing an increase of the accumulation nutrients in soybean seeds.

Such comparable findings have been noticed by shah et al. (2017) who demonstrated that the early sowing has elapsed more time and the growth period which accumulated more photo-assimilates. In addition, high temperature caused deformed seeds during the delayed planting. This might be due to the short vegetative growth, long reproductive and grain filling duration which significantly increased the 100 -seed weight. Similar results were confirmed by Pedersen and Lauer (2004) who reported that early sowing of soybean had more growth period to accumulate more photo-assimilates which increased the average seed weight than late sowing.

\subsubsection{Seed, straw and biological yield}

Seed, straw and biological yield were studied under varying sowing dates (Table 1). Differences ( $\mathrm{p}$ $<0.05$ ) on the soybean yields were observed due to early and mid-May planting compared to late sowing time. Regarding seed yield, it was notably influenced $(\mathrm{p}<0.05)$ by the three planting dates of soybean, especially at May 5 planting (Table 1). Results also showed that highest seed yield of soybean was obtained at May 5 (1314.56 kg/fed) followed by May 20 (1243.91 kg/fed) and June 3 (909.60 kg/fed). The enhancement of seed yield at May 5 is probably attributed to the long duration period of growth and development of plants, which were achieved by their potential ability for up-taking nutrients and intercepting light, then increased seed yield (Ahmed et al., 2010).

Table 1. Effect of planting dates on soybean yield and its components combined over two growing seasons (2018 and 2019).

\begin{tabular}{cccccccccc}
\hline $\begin{array}{c}\text { Planting } \\
\text { dates }\end{array}$ & $\begin{array}{c}\text { Plant } \\
\text { height } \\
\text { (cm) }\end{array}$ & $\begin{array}{c}\text { Number } \\
\text { of pods } \\
\text { /plant }\end{array}$ & $\begin{array}{c}\text { Weight } \\
\text { of pods } \\
\text { /plant } \\
\text { (g) }\end{array}$ & $\begin{array}{c}\text { Number } \\
\text { of seeds } \\
\text { /plant }\end{array}$ & $\begin{array}{c}\text { Weight } \\
\text { of seeds } \\
\text { /plant } \\
\text { (g) }\end{array}$ & $\begin{array}{c}\text { Weight } \\
\text { of 100 } \\
\text { seeds } \\
(\mathbf{g})\end{array}$ & $\begin{array}{c}\text { Seeds } \\
\text { (kg/fed) }\end{array}$ & $\begin{array}{c}\text { Straw } \\
\text { (kg/fed) }\end{array}$ & $\begin{array}{c}\text { Biology } \\
(\mathbf{k g} / \mathbf{f e d})\end{array}$ \\
\hline $\begin{array}{c}\text { May 5 } \\
\text { May 20 }\end{array}$ & 98.95 & 59.72 & 28.90 & 93.39 & 17.17 & 17.97 & 1314.56 & 2806.43 & 4120.99 \\
June 3 & 86.70 & 51.53 & 28.13 & 86.82 & 16.80 & 18.45 & 1243.91 & 2936.90 & 4180.81 \\
\hline $\begin{array}{c}\text { LSD at } \\
\mathbf{0 . 0 5}\end{array}$ & $\mathbf{2 . 5 2}$ & $\mathbf{2 . 9 4}$ & $\mathbf{1 . 7 3}$ & $\mathbf{3 . 0 9}$ & $\mathbf{0 . 6 6}$ & $\mathbf{0 . 6 1}$ & $\mathbf{6 3 . 5 7}$ & $\mathbf{1 2 9 . 5 0}$ & $\mathbf{1 4 6 . 2 0}$ \\
\hline
\end{tabular}

\subsection{Effect of weed control treatments}

Furthermore, no significant difference was obtained between May 5 and 20 on straw and biological yield (Table 1). Whereas, planting at May 5 and 20 had significant effect $(\mathrm{p}<0.05)$ on straw and biological yield in comparison with delayed sowing (June 3). Maximal straw and biological yield (2936.90 and $4191.22 \mathrm{~kg} / \mathrm{fed}$, respectively) were realized at May 20 and the lowest yields (1960.97 and $2870.57 \mathrm{~kg} / \mathrm{fed}$, respectively) which were noticed at June 3 plantation. Reduction in straw and biological yield was possibly linked to shortest plant 
height, No. of plant/ $\mathrm{m}^{2}$, No. of pods/plant, and lower dry matter accumulation/plant. These results are well supported by the investigations of Nagalamu $\boldsymbol{e t}$ al . (2012). Moreover, these results were also agreed with the observations of plant height and No. of pods/plant as it is clear in Table 1)

\subsubsection{Plant height}

Plant height significantly influenced by the applied herbicide treatments and hand hoeing twice of weeds in comparison with untreated plants (control plot), but it had no differences $(p>0.05)$ between the three weed control treatments including goal and omega herbicide and hand hoeing twice as indicated in Table 2. The values of plant height of soybean were increased in the following order: goal $(96.51 \mathrm{~cm})$ followed by omega $(96.34 \mathrm{~cm})$ and hand hoeing $(95.50 \mathrm{~cm})$ as compared with un-weeded check $(91.89 \mathrm{~cm})$.

\subsubsection{No. and weight of pods /plant}

It is obvious clear from the data of No. and weight of pods/plant varied vitally due to different weed control treatments (Table 2). No. and weight of pods/plant significantly influenced by the application of herbicide treatments and hand hoeing twice compared to the untreated plants (control), but they have no differences $(p>0.05)$ between the omega, goal herbicide and hand hoeing twice procedure. The maximal and lowest No. of pods were recorded for the use of hand hoeing and under un-weeded treatment; (63.63 and 50.12 pod/plant). These observations were supported by the findings of Odeleye et al. (2007) who indicated that the flowering of soybean significantly delayed with high weed density due to high weed in infestation for the growth and development of the soybean.

Furthermore, omega herbicide notsignificantly enhanced weight of pods/plant (28.60 g) over goal (27.73), hand hoeing (28.41) and the control (21.62). This finding is possibly credited to the decreased in competition between associated weeds and soybean plants due to omega herbicide, resulting in an increase of the metabolites synthesized by soybean leaves; thus, soybean plants were able to form more No. of flowers and consequently higher No. of pods/plant when compared to the un-weeded treatment.

\subsubsection{No. and weight of seed/plant and weight of 100-seed}

Table (2) presents the effect of different weed control treatments on No. and weight of seeds/plant and 100-seed weight of soybean plant. Experimental data confirmed that there were no significant differences among each of the three weed control treatments (goal, omega and hand hoeing twice) on these studied parameters of soybean plant, however omega and hand hoeing showed significant effect for No. of seeds/plant over goal herbicide application. Additionally, goal, omega and hand hoeing have remarkable impacts relative to their control ( $p<$ 0.05). The application of hand hoeing twice recorded the highest No. and weight of pods/plant and 100seed weight (91.94, 17.68 and $18.35 \mathrm{~g}$, respectively), whilst the lowest values of the above were realized for control (64.60, 12.75 and $16.22 \mathrm{~g}$, respectively).

\subsubsection{Seed, straw and biological yield}

As presented in Table (2), omega, goal and hoeing treatments exerted a significant influence $(\mathrm{p}<$ 0.05 ) on seed, straw and biological yield of soybean relative to control, especially hoeing (for seed yield), and goal (for straw and biological yield). Seed yield (kg/fed) was significantly increased when using twohand hoeing in both of the two growing seasons $(1235.72 \mathrm{~kg} / \mathrm{fed})$ in comparison with un-weeded check (control) (983.03 kg/fed). Such increase in seed yield may be due to the lowest weed intensity in soybean plants due to the positive effect of weed management by hand hoeing which provided ideal environment conditions (e.g. light, water and nutrients) to the crop for better reproductive potential, which stimulating the improvement of seed yield (Vijay et al., 2018). Similar observations have been also presented in earlier studies (Megawer and Seif El-Yazal 2008; and Hamoda et al., 2017). Moreover, the reduction in seed yield following control may be ascribed to heavy infestation of weeds in soybean field which increased the competition between soybean and weeds during the growth and development phases which decreased the uptake of water and nutrients, as well as reducing photosynthesis by over shading of the crop, which reduce seed yield (Shaikh et al., 2010; and Kumagai and Takahashi, 2020). The improvement in seed yield after hand hoeing treatment was consistent with the observations of No. of pods/plant, No. of seeds/plant, weight of seeds/plant and weight of 100-seed as presented in Table (2).

On the other hand, goal herbicide resulted the maximum straw and biological yield which were 2907.51 and $4101.91 \mathrm{~kg} / \mathrm{fed}$, while the lowest yields (1787.25 and $2770.28 \mathrm{~kg} / \mathrm{fed})$ were obtained from un-weeded treatment. Peer et al. (2013) reported that different weed control treatments favorably influenced the biological yield. They indicated that weed free treatments increased the biological yield by $52 \%$ as compared to control plots. 
Table 2. Effect of weed control treatments on soybean yield and its components, combined over two growing seasons (2018 and 2019).

\begin{tabular}{cccccccccc}
\hline $\begin{array}{c}\text { Weed } \\
\text { control } \\
\text { treatments }\end{array}$ & $\begin{array}{c}\text { Plant } \\
\text { height } \\
\text { (cm) }\end{array}$ & $\begin{array}{c}\text { Number } \\
\text { of bods } \\
\text { /plant }\end{array}$ & $\begin{array}{c}\text { Weight } \\
\text { of bods } \\
\text { /plant } \\
\text { (g) }\end{array}$ & $\begin{array}{c}\text { Number } \\
\text { of seeds } \\
\text { /plant }\end{array}$ & $\begin{array}{c}\text { Weight } \\
\text { of seeds } \\
\text { /plant } \\
\text { (g) }\end{array}$ & $\begin{array}{c}\text { Weight } \\
\text { of 100 } \\
\text { seeds } \\
(\mathbf{g})\end{array}$ & $\begin{array}{c}\text { Seeds } \\
\text { (kg/fed) }\end{array}$ & $\begin{array}{c}\text { Straw } \\
\text { (kg/fed) }\end{array}$ & $\begin{array}{c}\text { Biology } \\
\text { (kg/fed) }\end{array}$ \\
\hline $\begin{array}{c}\text { Omega } \\
\text { Goal }\end{array}$ & 96.34 & 61.57 & 28.60 & 91.20 & 16.73 & 17.80 & 1210.94 & 2734.90 & 3945.84 \\
$\begin{array}{c}\text { Hoeing } \\
\text { Control }\end{array}$ & 95.51 & 60.90 & 27.73 & 85.18 & 16.28 & 17.85 & 1194.40 & 2907.51 & 4101.91 \\
\hline $\begin{array}{c}\text { LSD at } \\
\mathbf{0 . 0 5}\end{array}$ & $\mathbf{1 . 9 9}$ & $\mathbf{3 . 0 2}$ & $\mathbf{1 . 7 5}$ & $\mathbf{3 . 6 4}$ & $\mathbf{0 . 6 8}$ & $\mathbf{0 . 8 5}$ & $\mathbf{5 1 . 3 0}$ & $\mathbf{1 1 2 . 6 0}$ & $\mathbf{1 6 3 . 9 0}$ \\
\hline
\end{tabular}

3.3. Effect of the interaction between planting dates and weed control treatments

The impact of planting dates and weed control treatments are shown in Table (3). Results confirmed that the difference in plant height, weight of pods and weight of 100 -seed were not statistically significant ( $\mathrm{p}>0.05$ ).

3.3.1. No. of pods and No. and weight of seeds/ plant

The effect of various planting dates and the applied weed control treatments on No. of pods and No. and weight of seeds/plant were recorded in Table (3). The combined effect of planting date at May 5 and hand hoeing twice produced the highest No. of pods and No. and weight of seeds (67.65 pod/plant, $106.27 \mathrm{seed} / \mathrm{plant}$ and $19.63 \mathrm{~g} / \mathrm{plant}$, respectively), whereas the lowest values (47.09 pod/plant, 57.99 seed/plant and $11.27 \mathrm{~g} /$ plant) were realized as a result of delayed planting time at June 3 and control check.
3.3.2. Seed, straw and biological yield

Mean values of the seed yield of different sowing dates and weed control treatments are presented in Tables (3). Planting on May 5 and the application of hand hoeing twice showed an increasing seed yield (1427.67 kg/fed) as compared to the interaction of planting on June 3 and unweeded check $(831.79 \mathrm{~kg} / \mathrm{fed})$. These observations were also noticed for No. of pods/plant, weight of pods/plant, No. seeds/plant and weight of seeds/plant.

On the other hand, straw and biological yield of soybean were found to be significantly largest due to the interaction between planting on May 20 and hand hoeing twice (3339.13 and $4673.09 \mathrm{~kg} / \mathrm{fed}$, correspondingly) than the interaction between the delayed planting time at June 3 and the control (1460.92 and $2292.71 \mathrm{~kg} / \mathrm{fed}$, respectively).

Table 3. Effect of the interaction between planting dates and weed control treatments on soybean yield and its components, combined over two growing seasons (2018 and 2019).

\begin{tabular}{|c|c|c|c|c|c|c|c|c|c|c|}
\hline \multicolumn{2}{|c|}{ Treatment } & \multirow[b]{2}{*}{$\begin{array}{c}\text { Plant } \\
\text { height } \\
(\mathbf{c m})\end{array}$} & \multirow[b]{2}{*}{$\begin{array}{c}\text { Number } \\
\text { of bods } \\
\text { /plant }\end{array}$} & \multirow{2}{*}{$\begin{array}{c}\text { Weight } \\
\text { of bods } \\
\text { /plant } \\
\text { (g) }\end{array}$} & \multirow[b]{2}{*}{$\begin{array}{c}\text { Number } \\
\text { of seeds } \\
\text { /plant }\end{array}$} & \multirow{2}{*}{$\begin{array}{c}\text { Weight } \\
\text { of } \\
\text { seeds } \\
\text { /plant } \\
\text { (g) }\end{array}$} & \multirow{2}{*}{$\begin{array}{l}\text { Weight } \\
\text { of } 100 \\
\text { seeds } \\
\text { (g) }\end{array}$} & \multirow[b]{2}{*}{$\begin{array}{c}\text { Seeds } \\
\text { (kg/fed.) }\end{array}$} & \multirow[b]{2}{*}{$\begin{array}{c}\text { Straw } \\
\text { (kg/fed.) }\end{array}$} & \multirow[b]{2}{*}{$\begin{array}{c}\text { Biology } \\
\text { (kg/fed.) }\end{array}$} \\
\hline $\begin{array}{l}\text { Planting } \\
\text { date }\end{array}$ & $\begin{array}{c}\text { Weed } \\
\text { control }\end{array}$ & & & & & & & & & \\
\hline & Omega & 100.65 & 59.26 & 30.92 & 105.50 & 18.46 & 17.99 & 1396.88 & 3120.29 & 4517.17 \\
\hline May & Goal & 98.83 & 61.93 & 29.97 & 92.58 & 17.17 & 18.34 & 1359.83 & 3113.25 & 4473.08 \\
\hline \multirow[t]{3}{*}{5} & Hoeing & 99.83 & 67.65 & 31.06 & 106.27 & 19.63 & 19.12 & 1427.67 & 3138.96 & 4566.63 \\
\hline & Control & 96.51 & 50.03 & 23.65 & 69.21 & 13.41 & 16.44 & 1073.88 & 1853.21 & 2927.09 \\
\hline & Omega & 99.38 & 65.06 & 30.81 & 94.38 & 17.63 & 18.82 & 1313.50 & 3040.25 & 4353.75 \\
\hline May & Goal & 102.63 & 61.92 & 29.13 & 90.64 & 17.17 & 18.67 & 1284.75 & 3320.58 & 4605.33 \\
\hline \multirow[t]{3}{*}{20} & Hoeing & 99.25 & 65.90 & 30.08 & 95.67 & 18.83 & 19.38 & 1333.96 & 3339.13 & 4673.09 \\
\hline & Control & 96.84 & 53.25 & 22.51 & 66.58 & 13.57 & 16.95 & 1043.42 & 2047.63 & 3091.05 \\
\hline & Omega & 88.99 & 60.39 & 24.08 & 73.73 & 14.09 & 16.61 & 922.46 & 2044.17 & 2966.63 \\
\hline June & Goal & 88.07 & 58.86 & 24.10 & 72.31 & 14.51 & 16.54 & 938.63 & 2288.71 & 3227.34 \\
\hline \multirow[t]{2}{*}{3} & Hoeing & 87.41 & 57.33 & 24.07 & 73.98 & 14.57 & 16.54 & 945.54 & 2050.08 & 2995.62 \\
\hline & Control & 82.32 & 47.09 & 18.71 & 57.99 & 11.27 & 15.29 & 831.79 & 1460.92 & 2292.71 \\
\hline \multicolumn{2}{|c|}{ LSD at 0.05} & n.s & 5.25 & n.S & 6.31 & 1.17 & n.s & 88.85 & 195.00 & 215.90 \\
\hline
\end{tabular}

\section{Conclusions}

In this study, the effect of two different agricultural treatments (planting dates and weed control) on yield and its components was assessed. Results indicated that early sowing at May 5 favored the yield components of soybean. Moreover, the yield parameters of soybean decreased when delayed planting at June 3 compared to other two planting date treatments May 5 and 20. Furthermore, two hand weeding at 20 and 40 DAS and omega 
herbicide were the best of the applied weed control practice. Additionally, the interaction between the early planting date and hand hoeing twice showed better performance of soybean plants as compared to the other applied treatments.

\section{References}

Abd El-Hamid, M. T. and I. M. El-Metwally (2008). Growth, nodulation, and yield of soybean and associated weeds as affected by weed management. Planta Daninha, Viçosa-mg, 26 (4): 855-863.

Ahmed, M. S.; M. M. Alam and M. Hasanuzzaman (2010). Growth of different Glycine $\max$ L. Merril varieties as affected by sowing dates. Middle East J. Sci. Res., 5: 388391.

Bastidas, A. M.; T. D. Setryono; A. Dobermann; K. G. Cassman; R. W. Elmore; G. L. Graef and J. E. Specht (2008). Soybean sowing date: The vegetative, reproductive, and agronomic impacts. Crop Sci., 48:727-740.

Chen, G. and P. Wiatrak (2010). Soybean development and yield are influenced by planting date and environmental conditions in the southeastern coastal plain, United States. Agron. J. 102:1731-1737.

Das, T.K.; S. B. Singh; R. K. Sairam; K. Annapurna and D.K. Sharma (2010). Studies on pre- and post-emergence use of metribuzin in soybean and its after effects on succeeding wheat. Ph.D. Thesis, Indian Agricultural Research Institute, New Delhi.

Devi, K. N.; A. K. Vyas; M. S. Singh and N. G. Singh (2011). Effect of bioregulators on growth, yield and chemical constituents of soybean (Glycine max L.). J. Agric. Sci., 3(4):151-159.

El Toum, G.; N. Khalifa and A. S. A. Hussain (2020). Effect of planting date and sowing method on yield and grain quality of soybean (Glycine $\max$ L.) under North Sudan conditions. Mor. J. Agri. Sci. 1(2): 91-94.

FAO (2018). FAO Statistical Databases (FAOSTAT). Available by Food and Agriculture Organization of the United Nations.

Gomez, K. A. and A. A. Gomez (1984). Statistical Procedures for Agric. Res. $2^{\text {nd }}$. Ed., John Wiley\& Sons, ISBN: 978-0-471-87092-0.

Hamoda, A. M.; G. A. Sary; E. Shokr and A. Roshdy. (2017). Effect of some weed control treatments and plant density on two soybean varieties and associated weeds. Anna. Agric. Sci., Moshtohor. 55(1): 1-10.

Kumagai, E. (2018). Effect of early sowing on growth and yield of determinate and indeterminate soybean (Glycine $\max (\mathrm{L}$.) Merr.) cultivars in a cool region of northern Japan. J. Agric. Meteor., 74 (1): 18- 28.
Kumagai, E. and T. Tomoki (2020). Soybean (Glycine $\max (\mathrm{L}$.$) Merr.) yield reduction due to$ late sowing as a function of radiation interception and use in a cool region of Northern Japan. Agron., 10 (66): 1-14.

Kumar, M. S.; D. Singh and V. U. M. Rao (2005). Effect of planting dates on yield and yield components of soybean genotypes. Haryana $\mathrm{J}$ Agron., 21: 202-205.

Megawer, E. A. and M. A. Seif El-Yazal (2008). Integrated effect of varieties, plant densities and weed control treatments on chemical composition and yield of soybean grown in newly reclaimed soil. Fayoum J. Agric. Res. Dev., 22 (2): 258-274.

Ngalamu, T.; S. Meseka and M. Ashraf (2012). Performance of soybean (Glycine $\max \mathrm{L}$. Merrill) genotypes under different planting dates in Sennar State of the Sudan. J. Appl. Biosci., 49: 3363-3370.

Odeleye, F. O.; O. M. O. Odeleye and O. A. Dada (2007). The performance of soybean Glycine $\max L$. under varying weeding regimes in South Western Nigeria. Not. Bot. Hort. Agrobot. Cluj., 35 (1), 1842-4309.

Pedersen, P. and J. G. Lauer (2004). Soybean growth and development in various management systems and planting dates. Crop Sci., 44(2): 508 -515 .

Peer, F. A.; H. Badrul; B. A. Lone; S. Qayoom; A.Latief; B. A. Khanday; P. S. Singh and G. Singh (2013). Effect of weed control methods on yield and yield attributes of soybean. African J. Agric. Res., 8(48):6135-6141.

Pinke, G.; K. Blazsek; L. Magyar; K. Nagy; P. Karácsony; B. Czúcz and Z. Botta- Dukát (2016). Weed species composition of conventional soybean crops in Hungary is determined by environmental, cultural, weed management and site variables. Weed Res., 56(6):470-481.

Rahman, L. (2001). Soybean: production and food use technology (in Bangalia) BAU-USDA soybean project. Department of Genetic and Plant Breeding, Mymensingh, pp:1-24.

Ray, C. L.; E. R. Shipe and W. C. Bridges (2008). Planting date influence on soybean agronomic traits and seed composition in modified fatty acid. Crop Sci., 48(1):181-188.

Robinson, A. P.; S. P. Conley; J. J. Volenec and J. B. Santini (2009). Analysis of high yielding, early planted soybean in Indiana. Agron. J., 101:131- 139 .

Ruhul, A. A. K. M.; S. R. A. Jahan; M. F. Karim; M. Hasanuzzaman (2009). Growth dynamics of soybean (Glycine max L.) as affected by varieties and timing of irrigation. Americ. Euras. J. Agron., 2: 95-103.

Setiyono, T. D.; A. Weiss; J. Specht; A. M. Bastidas; K. G. Cassman and A. Dobermann, 
(2007). Understanding and modeling the effect of temperature and daylength on soybean phenology under high- yielding conditions. Field Crops Res., 100, 257-271.

Shah T.; N. Zaffar; Kalsoom; A. Ahmad and A. Jalal (2017). Yield and quality traits of soybean cultivars response to different planting windows. Int. J. Statis. Actu. Sci., 1(2): 55-59.

Shaikh, A. A.; M. M. Desai; S. B. shinde and A. D. Tambe (2010). Yield and quality of soybean [Glycine max, (L.) Merrill] as influenced by integrated weed management. Int. J. of Agric. Sci., 6 (2): 1:3.

Sinclair, T. R.; N. Neumaier; J. R. B. Farias and A. L. Nepomuceno (2005). Comparison of vegetative development in soybean cultivars for lowlatitude environments. Field Crops Res., 92:53-59.

Snedecor, G. W. and W. G. Cochran (1980). Statistical methods. Seventh edition. Iowa State University Press, Ames, Iowa, USA.
Tourn, H. and F. N. Uygur (2019). Effect of crop rotations on winter wild oat (Avena sterilis L.) populations in Osmaniye province wheat sown areas. J. Res. Weed Sci., 2(4):345-357.

Vijay, J.; M. Mallareddy; C. K. Shekar and B. Padmaja (2018). Effect of sequential application of pre and post-emergence herbicides on growth, yield attributes and yield of soybean (Glycine max), Int. J. Pure App. Biosci., 6 (2): 238-241.

Yari, V.; F. Amin, M. Abbas, M. Meysam, R. Naseri; G. Mahboubeh and L. Ahmad (2013). Yield and yield components of soybean cultivars as affected by planting date. Bull. Env. Pharmacol. Life Sci., 2 (7): 85-90.

Zhang, Q. Y.; Q. L. Gao; S. J. Herbert; Y. S. Li and A. M. Hashemi (2010). Influence of sowing date on phenological stages, seed growth and marketable yield of four vegetable soybean cultivars in North-eastern USA. African J. Agric. Res., 5:2556-2562. 


\section{تأثير مواعيد الزراعة ومعاملات مقاومة الحشائش على محصول فول الصويا ومكوناته

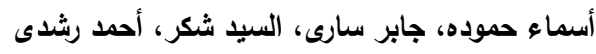

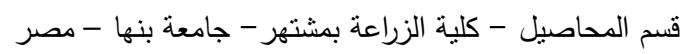

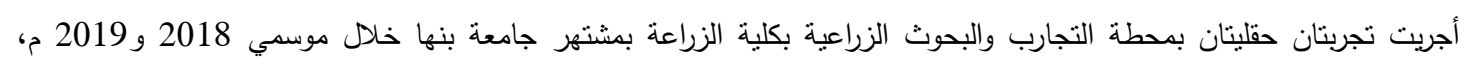

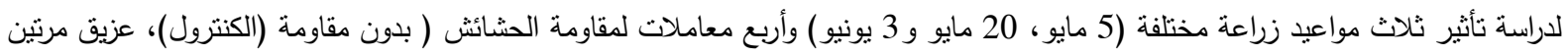

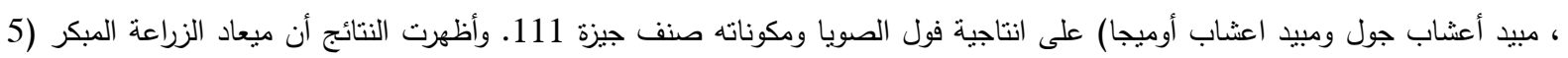

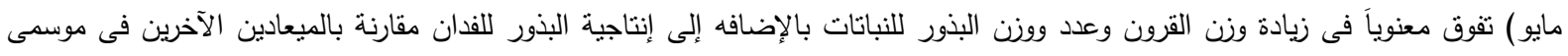

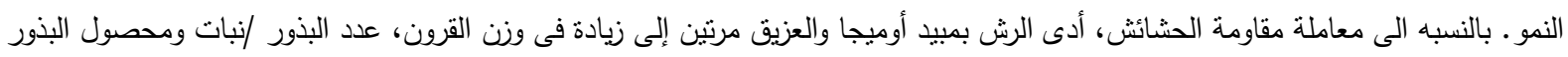

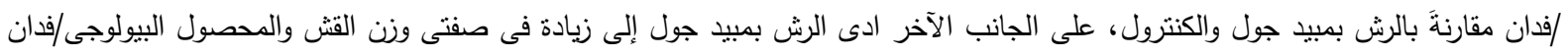

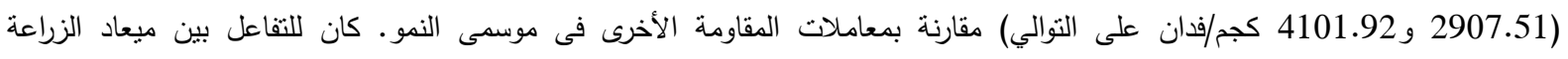

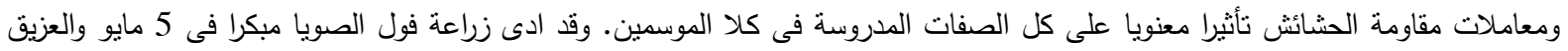

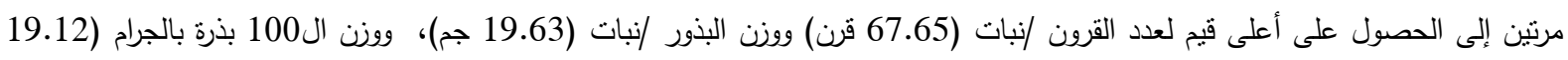
جم) وكذا محصول البذور /فدان بالكجم (1427.67 كجم/فدان). 